\title{
The Influence of Science Literacy-Based Teaching Material towards Science Achievement
}

\author{
Avikasari $^{1}$, Rukayah $^{2}$, Mintasih Indriayu $^{3}$ \\ ${ }^{1}$ Master Program of Elementary School Teacher Training and Education, Sebelas Maret University, Indonesia \\ ${ }^{2,3}$ Postgraduate Departement, Sebelas Maret University, Indonesia
}

\section{Article Info \\ Article history: \\ Received Jun 26, 2018 \\ Revised Jul 28, 2018 \\ Accepted Aug 24, 2018}

Keyword:

Science Achievement

Science Literacy

Teaching Material

\begin{abstract}
Based on PISA assessment result in 2015 on science; Indonesia ranks 69 out of 79 countries. Meanwhile, in science literacy, Indonesia ranks 62 out of 69 countries that are evaluated. That assessment result shows that science achievement and science literacy ability of Indonesian students are low. One of some factors that influences it is the selection of learning resource that does not explain science concept for students. This research is conducted to know the influence of the use of science literacy-based teaching material based on the improvement of fourth grade students' science achievement. This research is a quantitative research that uses an experimental method. This research is conducted at two elementary schools in Gunungpati, Semarang. The subjects of this research are 46 fourth grade students. The data were collected by using pre-test and post-test to know the students' score. This research shows that pre-test mean score is 39.935 and the posttest 1 mean score is 66.891. Meanwhile, t-tests show significance 0.000 $(<0.05)$ meaning that there is the difference between pre-test and post-test. Therefore, there is influence on the use of science literacy-based teaching material based on fourth grade students' science achievement.
\end{abstract}

Copyright $(C) 2018$ Institute of Advanced Engineering and Science. All rights reserved.

\section{Corresponding Author:}

Avikasari,

Departement of Elementary School Teacher Training and Education,

Sebelas Maret University, Indonesia,

Jl. Ir. Sutarmi No. 36A, Jebres, Surakarta, Jawa Tengah, Indonesia (57126).

Email: aviekasari@gmail.com

\section{INTRODUCTION}

Science is one of the subjects learned by the students from the early grades. By learning science, students know about the nature of the environment and the human body. In learning science, the priority is on the process and direct experience. It aims to make the students able to understand the concept of science, understand the environment, and also directly interact with nature [1].

The analysis results of Program for International Student Assessment (PISA) in 2015 on mathematics, science, and reading conducted by Organization of Economic Cooperation and Development (OECD) shows that the quality of Indonesian education ranks 69 out of 69 countries that are evaluated [2]. Besides being evaluated by PISA, the quality of Indonesian education is also evaluated by TIMSS in 2015. It shows that Indonesia ranks 44 out of 47 countries [3]. Both those assessments show that the quality of science education and science literacy in Indonesia are still low so that improving Indonesian students' science achievement and science literacy are needed. Science literacy mastery should be encouraged by the teacher so that it will be embedded on the students. With the science facts, students are expected to have learning skills and decision making skills [4].

Science literacy ability is an ability that students should have. Science literacy can be defined as someone's ability in mastering science, communicating science, also applying science knowledge to solve the problem so that he or she has attitude and high sensitivity to him/herself and his/her environment, and has the 
ability to take decision based on science considerations [5]. This definition is strengthened by PISA 2015 that defines science literacy as the ability to understand science phenomenon and science concept as a reflective citizen. Through science literacy, someone is expected to be able to ask, find, or determine an answer to the questions that are generated from the curiosity of everything. That curiosity should be directed to scientific attitude and scientific mind so that students can solve problems that they face scientifically.

However, the reality on the field shows that the literacy rate of science students is still low; not only the students' science literacy but also the students' science learning achievements are still low. The students' low ability on science literacy and science learning achievement is influenced by several factors. One of those several factors is the learning resources used in the classroom learning activities. [6] points out that one of the main problems in supporting integrated science lessons is the lack of reference or teaching material as a means to support the lesson. The students will achieve a good learning achievement if they understand and master the learning concept well. Learning achievements are also related to the students' understanding on the materials [7]. Science learning achievements are the achievement of science learning activities manifested in students' behavior change known by evaluating students' knowledge [8]. In this case, learning achievements can be seen from the score of the learning criteria based on the passing grade (KKM) that has been assigned by the school [9].

The students' inadequate understanding of the concept is caused by the fact that the teachers still use limited. Learning resources that are used in learning do not support science literacy to be fluent and the presentation of the material in the book is not in accordance with the level of the students' understanding. Based on these problems, it is known that the learning materials are one of the important components. Teaching materials are a set of materials, either written or not, arranged in a systematic order so that it creates the environment or the atmosphere that allows students to learn [10]. Science teaching materials used by teachers and students at this time in is in the form of textbook designed according to 2013 curriculum. The 2013 curriculum textbook involves thematic learning with scientific approach. However, the material in this book is very limited so that it is not too effective to convey the concept of science to students. In addition, there are some basic competences (KD) that are not included in the book. Although 2013 curriculum books integrate scientific approach, the science literacy is not well-adjusted yet. Science literacy-based teaching material must contain at least four categories of science literacy namely science as the body of knowledge; science as a way to investigate; science as a way of thinking; and the interaction of science, technology and community [11].

To know whether science literacy-based teaching materials used by fourth grader in learning science is able to improve students' learning achievements, the test on the use of science literacy-based learning material is done. The test is designed to know whether there is a difference between the score obtained before and after the learning activities by using science literacy-based teaching materials are conducted. The improved performance in learning science will affect the students' understanding of the concept as well as their literacy in the classroom learning activities. Therefore, the researcher formulates that the purpose of this research is to know the influence of science literacy-based teaching materials in improving fourth grade elementary school students' science learning performance.

\section{RESEARCH METHOD}

This research applied the experimental method, type experimental in this research is the one group pretest-posttest. Because this research to examine the influence of science literacy-based teaching material on the fourth grade students' science achievement improvement. This research was conducted in two elementary schools in Gunungpati, Semarang. Sampling techniques in this research using simple random sampling. The subjects of this research are 46 fourth grade students in Gunungpati, Semarang in the academic year of $2017 / 2018$. The source of the data in this research is the test score got by the students before and after using teaching materials.

The research data were collected by using test. Analysis test in this research using ITEMAN software, where is the validity and reliability using significance $5 \%$. The tests used are 30 multiple choice question. The test stated is valid because more than 0.291 . Whereas the results of the analysis using ITEMAN software reliability gained 0.848 , so the question of reliability. The test was used to measure students' achievement before and after using science literacy-based teaching material.

The tests used in this research were pre-test and post-test after learning activity. The results of the test were analyzed by using non-independent t-test in which t-obtained was compared with t-table. If tobtained $>\mathrm{t}$-table, the hypothesis is accepted (Ho is rejected), if t-obtained $<\mathrm{t}$-table, the hypothesis is rejected (Ho is accepted). Non-independent t-Test formula is [12]: 


$$
t=\frac{\bar{x}_{d}-\mu_{0}}{S_{d} / \sqrt{n}}
$$

\section{RESULTS AND ANALYSIS}

\subsection{Result}

This research aims to know the influence of science literacy-based teaching material towards students' learning achievement. The data obtained in this research are obtained by using objective multiplechoice tests involving 30 questions that are given before and after learning process. Questions given are related to science literacy-based teaching material. Students' pre-test and post-test score result can be seen in table 1.

Table 1. The Results of Pre-Test and Post-Test Score in Learning Science

\begin{tabular}{lcc}
\hline & Pretest & posttest \\
\hline Mean & 1837 & 3077 \\
Average & 39.935 & 66.891 \\
Maximum & 53 & 87 \\
Minimum & 23 & 50 \\
Media & 40 & 67 \\
Mode & 37 & 67 \\
\hline
\end{tabular}

Based on table 1, it shows that pre-test and post-test result have a significant result. In pre-test, 46 students get total score of 1873 with 39.935 as the mean score. That pre-test result does not meet the determined passing grade $(\mathrm{KKM})$ that is 60 . Meanwhile, in the post-test done after the teaching-learning process of science, the students get total score of 3077 with 66.891 as the mean score. That post-test score meet the determined KKM. Thus, there is an influence of the use of science literacy-based teaching material towards students' learning achievement. It can be concluded that there is improvement on science learning achievement of the fourth grade students in Gunungpati before and after teaching-learning process using science literacy-based teaching material is conducted.

The improvement in science learning achievement in this research is also measured by using nonindependent t-test by the help of SPSS software version 16. SPSS calculation is done to determine whether there is a significant difference between the results of the pretest and post-test in learning activities by using science literacy-based teaching material or not. Before conducting the non-independent t-test, the prerequisite test is conducted first. The prerequisite test is conducted to know whether the data obtained distribute normally and homogeneously or not. The result of prerequisite test can be seen in table 2 .

Table 2. The Result of Pre-Requisite Test

\begin{tabular}{|c|c|c|c|c|c|}
\hline & The tests were done & Test Type & Sig. & Test Decision & Conclusion \\
\hline \multicolumn{6}{|c|}{ prerequisite test } \\
\hline a. & Normality test & $\begin{array}{l}\text { Kolmogorov- } \\
\text { Smirnov }\end{array}$ & & & \\
\hline & Pretest & & 0.536 & $\mathrm{H}_{0}$ in accept & Normal data \\
\hline & Posttest & & 0.469 & $\mathrm{H}_{0}$ in accept & Normal data \\
\hline & Homogenitas test & Levene's test & 0.177 & $\mathrm{H}_{0}$ in accept & Homogenous data \\
\hline
\end{tabular}

Based on table 2, it shows that the result of pretest and post-test distribute normally and homogeneously. Normality testing is analyzed by using Kolmogorov-Smirnov. In pre-test, the researcher finds significant rate on 0.536 , higher than $\mathrm{a}=0.05$, so that $\mathrm{H}_{\mathrm{o}}$ is accepted meaning that the pre-test scores distribute normally. In post-test, the researcher finds significant rate on 0.469 , higher than $\mathrm{a}=0.05$, so $\mathrm{H}_{\mathrm{o}}$ is accepted meaning that the post-test scores distribute normally. Meanwhile, the homogenity tests on both pretest and post-test show significant rate on 0.177 , higher than $\mathrm{a}=0.05$, so that $\mathrm{H}_{\mathrm{o}}$ is accepted meaning that the pretest and post-test scores are homogeneous.

The result of the prerequisite tests shows that the data collected distribute normally and homogeneously. Afterwards, non-independent t-test can be conducted to know the difference between the result of pretest and post-test. The summary of non-independent t-test result by using SPSS 16 can be seen in table 3 .

IJERE Vol. 7, No. 3, September 2018 : 182-187 
Table 3. Non-Independent T-Test

\begin{tabular}{rcccc}
\hline Test Type & count & df & Sig. & Test Decision \\
\hline Paired Sample T-Test & -15.161 & 45 & 0.000 & Ho rejected \\
\hline
\end{tabular}

Based on table 3, the non-independent t-test is calculated by using non-parametric paired sample ttest. The result of non-independent T-test in pretest and post-test show that the significant rate is on 0.000 , lower than $\mathrm{a}=0.05$, so $\mathrm{H}_{\mathrm{o}}$ is rejected. The result also shows that there is significant difference between students' scores before and after using science literacy-based teaching material in fourth-grade.

\subsection{Analysis}

Try out was widely used to measure the achievement of student learning before and after using the science literacy-based teaching material and as an addition and a support for the data obtained from the test. Extensive testing was done on twenty four fourth-grade students of Sumurejo 02 primary school and twenty two fourth-grade students in Sadeng 03 primary school. On this extensive testing, both schools were given pretest before beginning the teaching and learning process using science literacy-based teaching material.

After the pretest, the students learned to use science literacy-based teaching material. The students learned the first material and worked on the "let's analysis" in groups. Once the students had finished answering questions, the teachers discussed the questions and explained the material further to expand the students' awareness even more. Afterwards, the students were encouraged to make observations as a group and make a report over the observation. The students were very enthusiastic in doing the observation because the students were able to identify the parts of the plant directly. The students presented the results of the observation as a group in the class. This presentation was aimed to make each group know the observation result from the other groups. Every knowledge belonging to one group will become their output, and this output will become the other groups' input [13].

Questions in the exercise and observation were designed for the students to get the concept of parts of animals and plants since by doing exercises related to the material, the students' understanding could be better. It is supported with states that the more the students learn about one topic, the better they are able to think about the topic [14]. The students were then given homework on the question about "thinking" scientifically, and it would be reviewed on the next meeting. Through science, the students also learn about the benefits of animals and plants for human life. This is supported with states that the students feel happy with the teaching materials that are associated with the surrounding phenomena because they can get new experience in applying the knowledge they got to perform analysis of the daily events in their environment [15].

By using science literacy-based teaching material, the students and teachers were to give inputs for improving the concept of the leaf, giving details of monocot and dicoted plant parts, and improving the quality of worksheets writing that could be easily understood by the students. The recommendation is used by the researcher for the improvement of the product being developed so that it can be used during the testing phase.

The final activity of the extensive test was by doing post-test after learning using science literacybased teaching material. The analysis on pretest and post-test of the try out used non-independent t-tests. ttest was done after the data were normal and homogenous. In pre-test, the researcher finds the significant rate on 0.536 , higher than $\mathrm{a}=0.05$, so that $\mathrm{H}_{\mathrm{o}}$ is accepted meaning that the pre-test scores distribute normally. In post-test, the researcher finds the significant rate on 0.469 , higher than $\mathrm{a}=0.05$, so $\mathrm{H}_{\mathrm{o}}$ is accepted meaning that the post-test scores distribute normally. Meanwhile, the homogenity tests on both pre-test and post-test show significant rate on 0.177 , higher than $\mathrm{a}=0.05$, so that $\mathrm{H}_{\mathrm{o}}$ is accepted meaning that the pretest and posttest scores are homogeneous. Once the data were normal and homogeneous, then the t-test can be done a ttest. The result of non-independent t-test in pretest and post-test show significant score on 0.000 , lower than a $=0.05$, so $\mathrm{H}_{\mathrm{o}}$ is rejected. The result also shows that there is significant difference between the students' scores before and after using science literacy-based teaching material in fourth grade. It proves that there is improvement on the students' learning achievement using science literacy-based teaching material. The improvement also happens on their understanding over science concept. In other words, the students' science literacy mastery also develops. Science literacy-based teaching material affects students' scientific attitude effectively [16].

The findings of this research are in line with some previous studies. Baiq find that the development of KAPRA science literacy-based teaching material is apt to be used in reaction flow learning [17]. Jbeili prove that the use of digital concept map in teaching learning process can improve fourth-grade students' learning achievement [18]. Science literacy-based teaching material science literacy-based teaching material 
can be used to imrpove the students' abilities on both science and technology [19]. Ünal find that there is animation technique effect in electromagnetic wave characteristic learning (EMWs) towards science teacher's achievement, and it is proven that there is significant difference between experimental group and control group $(p<0.05)$ [20]. The aforementioned experts show that science literacy-based teaching material can be used in science learning in high school and concept mastery through concept mapping can also increase the students' learning achievement. The difference between those studies and this one is on the subject and the research variables. In this research, science literacy-based teaching material is given in fourth grade students to know the influence towards the students' science achievement.

\section{CONCLUSION}

Based on the result of pre-test and post-test, the 46 students get an improvement in terms of score from mean score 39.935 in the pre-test to 66.891 in the post-test. The calculation of pretest and post-test score shows that there is increasing on the students' science learning achievement before and after using science literacy-based teaching material. The data in this research are also calculated by using SPSS version 16 to support the calculation result. In the calculation using SPSS version 16, the non-independent t-test is done by using non-parametric paired sample t-test. The significant score on non-independent t-test in both pre-test and post-test is in 0.000 , lower than $\mathrm{a}=0.05$, so $\mathrm{H}_{\mathrm{o}}$ is rejected. The result shows that there is significant different between students' score before and after using science literacy-based teaching material, so it can be concluded that there is influence on the use of science literacy-based teaching material towards grade 4 students' science learning achievement.

\section{ACKNOWLEDGEMENTS}

Acknowledgements are given to everyone who has helped in this article, and especially to the mentors who have provided data and data.

\section{REFERENCES}

[1] Anisa, Aries. (2017). Improving Critical Thinking Skills Learners Through Learning Natural Science Based On Local Potential of Jepara. Journal of Innovation Education of Science, 3 (1), 1-11.

[2] OECD-PISA. (2015). Assessing Scientific, Reading and Mathematical Literacy: A Framework for PISA 2015.

[3] Mullis, I.V.S., Martin, M.O., \& Editors (2013). TIMSS 2015 Assessment Frameworks. Chestnut Hill MA: TIMSS \& PIRLS International Study Center, Boston Collage.

[4] Betari, Mutiara Eka, Novi Yanthi, Deti Rostika. (2016). The Increase In The Literacy Ability of Science Students Through The Implementation Of Model-Based Learning Problems in Learning the Science in the Prymary School. Antologi UPI.

[5] Holbrook, J. \& Ramnikmae, M.. (2009). The meaning of scientific literacy. The international journal of environmental \& science education. 4(3): 275-288.

[6] Sugiyanto, Ika Kartika, dan Joko Purwanto. (2012). Development of Module Natural Science Based Integrated Science-Technology-Society-Environment Theme with Biogas Technology. Educational Journals. 42(1): 54-60.

[7] Hudojo, H. (1988). Teaching and Learning of Mathematics. Jakarta: Ministry of Education and Culture, the Directorate-General of Education.

[8] Susilowati, S.. (2017). Development of Materials Science Integrated Islamic Values To Improve The Learning Results Of The Natural Science. Journal of Innovation Education of Science, 3 (1), 78-88.

[9] Tiurma, Lisner dan Heri Retnawati. (2014). The Effectiveness of A Multimedia Learning Material of the Three Dimensions In Terms of Achievement and Interest In Learning Mathematics In High School. Educational Journals. 44(2): 175-187.

[10] Daryanto. (2014). Learning Thematic, Integrated, Integrated (2013 Curriculum)). Jogjakarta: Gava Media Hamalik.

[11] Chiapetta, E.L., D.A.Fillman \& G.H.Sethna. (1991). A Method to Quantify Major Themes of Scientific Literacy in Science Textbooks. Journal of Research in Science Teaching, 28 (8): 713-725.

[12] Sugiyono. (2010). Statistics for Research. Bandung: Alfabeta.

[13] Johnson, Ilaine B.. (2009). Contextual Teaching and Learning: Teaching and Learning Activities To Be Exciting and Meaningful. Bandung: Mizan Learning Center.

[14] Eggen, Paul Don Kouchak. (2012). Strategies and Models of Learning. Jakarta: PT Indeks.

[15] Suratsih, dkk.. (2009). The Development of Module-Based Genetic-Based Local Phenomenon. FMIPA Journal of Yogyakarta State University.

[16] Hapsari, Andri. (2015). Development of Materials Science Literacy-Based Science-Themed Universe for Class IX. FMIPA Article of Semarang State University.

IJERE Vol. 7, No. 3, September 2018 : $182-187$ 
[17] Nisa, Baiq Chairun, Suryati, Citra Ayu Dewi. (2013). Development of Materials Science Literacy-Based KAPRA Material Reaction Rate for Class XI SMA/MA. Scientific Journal Of Chemical Education "Hydrogen", (3)1: 228234.

[18] Ibrahim, M. A. Jbeili. (2013). The Impact of Digital Mind Maps on Science Achievement among Sixth Grade Students in Saudi Arabia. Procedia - Social and Behavioral Sciences, (10)3: 1078-1087.

[19] Efe Güçlüer dan Teoman Kesercioğlu. 2012. The Effect of Using Activities Improving Scientific Literacy on Students' Achievement in Science and Technology Lesson. International Online Journal of Primary Education, 1 (1), 8-13.

[20] Ibrahim Ünal, Nilüfer Okur, dan Serkan Kapucu. (2010). The effect of using animations on pre-service science teachers' science achievement. Procedia Social and Behavioral Sciences, 2, 5357-5361. 